\title{
Imigranci zarobkowi w Polsce: kim są ci, którzy skrywają się za liczbami? Przypadek ukraińskiej rodziny
}

\begin{abstract}
Streszczenie
Cudzoziemcy na polskim rynku pracy stanowią niewielki procent wszystkich zatrudnionych. Jednak od 2016 r. - czyli od chwili wprowadzenia „programu 500+” - obserwuje się dynamiczny wzrost tej grupy zatrudnionych, co sugeruje rosnące zapotrzebowanie na pracę imigrantów zarobkowych w Polsce. W populacji pracujących cudzoziemców najbardziej liczną grupę stanowią obywatele Ukrainy. Dane Banku Światowego, Ministerstwa Rozwoju, Pracy i Technologii, Zakładu Ubezpieczeń Społecznych i Najwyższej Izby Kontroli pozwoliły autorce zarysować społeczną sytuację imigrantów zarobkowych w Polsce, a także ukazać, że Polska jest (m.in.) ekonomicznie atrakcyjnym miejscem pracy szczególnie dla obywateli Ukrainy. Analiza danych statystycznych skłoniła autorkę do postawienia pytania: Kim są ci, którzy skrywają się za liczbami? Odpowiedzi na to pytanie dostarczyły wywiady biograficzno-narracyjne zrealizowane w ukraińskiej rodzinie. Wniosek płynący z całościowej analizy materiału empirycznego wskazuje, że państwo polskie w swojej polityce wewnętrznej z nie dość należytą troską zabezpiecza prawa ekonomiczne i prawa kulturowe imigrantów zarobkowych i ich dzieci.
\end{abstract}

\section{Słowa kluczowe:}

imigranci zarobkowi, rynek pracy, obywatele Ukrainy w Polsce

1 Adela Kożyczkowska, Wydział Nauk Społecznych, Uniwersytet Gdański, Polska, e-mail: adela.kozyczkowska@ug.edu.pl, ORCID ID: https://orcid.org/0000-0002-7952-1321. 


\begin{abstract}
Foreigners on the Polish labor market constitute a small percentage of all employees. However, since 2016 - that is, since the introduction of the "500+ program" - a dynamic increase in this group of employees has been observed, which suggests the growing demand for work of economic immigrants in Poland. In the population of working foreigners, the citizens of Ukraine constitute the most numerous group. Data from the World Bank, the Ministry of Development, Labor and Technology, the Social Insurance Institution and the Supreme Chamber of Control allowed the author to outline the social situation of economic immigrants in Poland, and to show that Poland is (among others) an economically attractive place to work, especially for Ukrainian citizens. The analysis of statistical data prompted the author to ask the question: Who are those who hide behind the numbers? The answer to this question was provided by biographical and narrative interviews conducted in a Ukrainian family. The conclusion resulting from the comprehensive analysis of the empirical material indicates that the Polish state in its internal policy with insufficient care protects the economic and cultural rights of economic immigrants and their children.
\end{abstract}

\title{
Keywords:
}

economic immigrants, labor market, Ukrainian citizens in Poland

\section{WPROWADZENIE}

Transformacja ustrojowa przełomu lat 80. i 90. ubiegłego wieku, która ogarnęła europejskie państwa bloku socjalistycznego, przyniosła ich obywatelom wiele problemów, na które ci w żaden sposób nie byli przygotowani. Transformacja, zrodzona z pragnienia wolności i zmian, miała - w wyobrażeniach wielu zwykłych ludzi - doprowadzić do wspólnotowego dobrobytu, polepszenia życia codziennego i poszerzenia wolności obywatelskiej.

Jednakże po latach można zaryzykować tezę, że transformacja ustrojowa wiązała się z gwałtownym zastąpieniem gospodarki planowania centralnego gospodarką wolnorynkową (patrz przykł.: Stiglitz, 2004, s. 141 i nn.). Transformacja systemowa wsparta była w istocie na działaniu, w którym ekonomia została przedłożona przed wszelkie inne idee i praktyki społeczno-polityczne. Niektóre państwa byłego bloku socjalistycznego - jak Polska czy Węgry - realizowały model transformacji w oparciu o pragmatyczne podejście, w którym brano pod uwagę choćby to, czy i jakie doświadczenie z przedsiębiorczością ma dane państwo. Inne kraje - przy-

2 Trzeba w tym miejscu wspomnieć - przykładowo - o badaniach Macieja Janowskiego, w któ- 
kładowo Rosja - przeszły tzw. terapię szokową wskutek bezkrytycznego wdrażania modelu gospodarki kapitalistycznej w wersji neoliberalnej (Stiglitz, 2004, s. 169).

Projektantami nowej posocjalistycznej Europy byli wysokiej klasy specjaliści od finansów, którzy przekonali świat polityki i świat codziennego życia, że jedynym sposobem walki z przeszłością jest natychmiastowe wyeliminowanie gospodarki planowania centralnego, gdyż ta pojmowana była jako ideowy filar socjalizmu. Argumentów praktycznych dostarczały dane finansowe, które - zdaniem ekonomistów - dowodziły, że socjalizm jest niewydolny ekonomicznie dlatego, że jego gospodarka jest niewydajna i niekonkurencyjna. Ratunek - i dla gospodarki, i dla transformacji - widziano wyłącznie w gospodarce wolnorynkowej jako wydolnej i konkurencyjnej, a więc zdolnej rywalizować na gospodarczej arenie światowej. Przekonywano również, że kapitalizm jest fundamentem demokracji liberalnej.

Transformacja ustrojowa państw posocjalistycznych zmieniła całkowicie obraz życia społecznego, a jej skutki okazały się dla człowieka posocjalistycznego nadzwyczaj bolesne, gdyż dobrobyt, lepsze życie i wolność obywatelska nie były tym, co w magiczny sposób zagościć mogłoby z dnia na dzień w życiu zwykłych ludzi. Zastosowana polityka ekonomiczna wymusiła dekonstrukcję całego obszaru pracy zarobkowej. Skutkowało to gwałtownym jego przeobrażeniem, czego swoistym symptomem były takie fenomeny społeczne jak „bezrobocie”, „wydajność” czy „konkurencyjność”. Wyjątkowo drażliwą kwestią stały się „płace” (szczególnie ich niskość) co decydowało o „samo(nie)zadowoleniu” robotnika/pracownika, które - obok bezrobocia - było bezpośrednim czynnikiem powodującym emigrację zarobkową.

W przypadku polskich doświadczeń transformacyjnych, co trzeba podkreślić, zjawisko emigracji zarobkowej nie było/nie jest czymś nowym. Obserwuje się jednak istotne przemiany społeczno-polityczne w tym obszarze: niegdysiejszych socjalistycznych „polskich gastarbeiterów” stopniowo zastąpili „polscy hydraulicy”, a tych powoli zastępują „polscy przedsiębiorcy”. Z kolei polscy politycy i ekonomiści dziś mówią wprost o konieczności wykorzystania potencjału intelektualnego, a także zawodowego polskiej emigracji dla polskiej gospodarki (Domarecki, 2015, s. 15). W ponowoczesnej gospodarce rynkowej chodzi bowiem o to, aby „zagospodarować” także emigrację zarobkową. Ta nie może już być postrzegana jako balast, lecz ma być ujmowana jako szansa rozwojowa. Politycy

rych autor „udowodnił”, że społeczeństwo polskie w swoich dziejach uformowało dość spójną myśl społeczno-gospodarczą. Znacząca jest tu druga połowa dziewiętnastego wieku, kiedy następuje rozwój idei liberalnej. Maciej Janowski dowodzi swoich tez m.in. poprzez analizę treści tekstów publicystycznych Bolesława Prusa, Elizy Orzeszkowej i Aleksandra Świętochowskiego (Janowski, 1998). 
i ekonomiści „pouczają” więc, że powinniśmy - my, Polacy - nauczyć się myśleć o emigrantach jako o naszym ,wielkim skarbie” i „niewykorzystanym potencjale” (Bos-Karczewska, 2015, s. 31-34).

Reasumując: u podstaw dotychczasowych polskich doświadczeń emigracyjnych stoją trzy zasadnicze motywy: (1) wychodźstwo z powodów ideologicznych (jak w przypadku emigracji Adama Mickiewicza czy Jerzego Giedroycia); (2) wychodźstwo z powodu pracy, której albo w ogóle nie ma, albo jest jej zbyt mało, bądź jest zbyt marnie opłacana, aby godnie z niej żyć; (3) wychodźstwo w celu zdobycia doświadczenia zawodowego i nauki/wiedzy poprzez m.in. podjęcie kształcenia w formalnych placówkach oświatowych i edukacyjnych za granicą (por. przykł.: Strama, 2017, s. 193-197). Jak zatem można wnioskować - niezależnie od tego czy powodem wyjazdu zarobkowego był/jest brak pracy czy zbyt niskie płace - emigracja zarobkowa nie jest nowym zjawiskiem w polskim życiu społecznym, ekonomicznym i politycznym. Stosunkowo nową sprawą jest obserwowany w dzisiejszej Polsce dwukierunkowy ruch migracyjny: Polacy wyjeżdżają za gracę w poszukiwaniu pracy bądź lepszej płacy albo po to, by zdobyć wiedzę i jednocześnie do Polski napływają cudzoziemcy - jak można sądzić - dokładnie z takich samych powodów.

Powyższy szkic polityczno-ekonomiczny stanowi kontekst dla interesującej mnie problematyki imigracji zarobkowej w Polsce, której populacja systematycznie wzrasta z roku na rok, a jej największą grupę stanowią dziś obywatele Ukrainy. Szczególnie interesuje mnie perspektywa zwykłych ludzi-imigrantów zarobkowych, dlatego też na przykładzie ukraińskiej rodziny zamierzam przyjrzeć się sytuacji społecznej cudzoziemców zarobkowych w Polsce. Egzemplifikację dla namysłu stanowi biografia rodziny - samotnej matki (po rozwodzie) i jej dwunastoletniego syna - która postanowiła stworzyć swój nowy dom w Polsce.

W pierwszej części artykułu - odnosząc się do danych Banku Światowego podjęłam próbę odpowiedzi na pytanie dlaczego Polska jest dziś atrakcyjna dla obywateli Ukrainy. W drugiej - w oparciu o dane Zakładu Ubezpieczeń Społecznych i Raportu Najwyższej Izby Kontroli - sygnalizuję sytuację społeczną (w tym edukacyjną) imigrantów. W trzeciej części - na podstawie biografii rodziny (na którą składają się dwa wywiady biograficzno-narracyjne matki i syna) - podejmuję próbę rekonstrukcji biografii imigracji zarobkowej, aby w części ostatniej odpowiedzieć na tytułowe pytanie: Kim są ci, którzy skrywają się za liczbami? 


\section{UKRAIŃCY W POLSCE, CZYLI PRÓBA ODPOWIEDZI NA PYTANIE, DLACZEGO POLSKA JEST DLA OBYWATELI UKRAINY ATRAKCYJNA}

Obywatele Ukrainy stanowią dziś w Polsce dominującą grupę imigrantów zarobkowych. Wielu Polaków uważa, że Ukraińcy przyjeżdżają do Polski „za pracą” dlatego, że polska kultura i język są bliskie kulturze i językowi ukraińskiemu. Jak się wydaje, to ważny aspekt podejmowanych decyzji, lecz - biorąc pod uwagę to, dokąd za pracą wyjeżdżają Polacy - jest on zbyt słabym czynnikiem motywacyjnym. Przykładowo: Polacy - za wyjątkiem terenów przygranicznych - nie wybierają Republiki Czeskiej jako kraju emigracji zarobkowej, pomimo że polska kultura i język są podobne do kultury i języka czeskiego; i pomimo że - jak pokazują badania Anny Szafrańskiej (2019, 2017; por. także: Stosunek do innych narodów, 2019, 2020) - Czesi są „ulubionym” narodem Polaków. Polacy chętniej wyjeżdżają do pracy do Niemiec mimo wielu narodowych stereotypów, które wygenerowane zostały wewnątrz relacji polsko-niemieckiej. Czynnikiem decydującym w tej sprawie jest bogactwo ekonomiczne państwa i to ono motywuje jednostki do podjęcia wysiłku wychodźstwa za pracą do tego kraju.

W przypadku obywateli Ukrainy prawdopodobnie głównym czynnikiem, który decyduje o wyborze kraju pobytu, jest zasadnicza różnica w rozwoju ekonomicznym Polski i Ukrainy. Różnica ta - jak się wydaje - obecnie zaspokaja aspiracje płacowe Ukraińców.

Analiza danych Banku Światowego dotyczących rozwoju gospodarczego Polski i Ukrainy w latach 1990-2019 (The World Bank, 2020a. The World Bank, 2020b. The World Bank, 2020c), pozwala rozpoznać trendy rozwojowe obu gospodarek. W 1990 r., czyli w roku poprzedzającym transformację ustrojową na Ukrainie, jej PKB wynosiło 81,457 mld USD, PKB per capita - 1569,758 USD, zaś PKB per capita PPP $^{3}$ - 7305,143 USD. W tym samym roku PKB Polski - to 65,978 mld USD, PKB per capita - 1731,21 USD, zaś PKB per capita PPP - to 6173,862 USD. Po blisko 30 latach zmian, w 2019 r. PBK Ukrainy wyniosło 153,781 mld USD, PKB per capita - 3659,227 USD, zaś PKB per capita PPP ustaliło się na poziomie 13 341,211 USD. Oznacza to, że zasobność gospodarki ukraińskiej, a także poziom bogactwa Ukraińców niemal się podwoiły. W tym samym 2019 r. PKB Polski wzrosło do 592,164 mld USD, a PKB per capita podniosło się do wartości 15 595,227 USD. Oznacza to aż dziewięciokrotny wzrost gospodarczy. PKB per

${ }^{3}$ Chodzi o siłę nabywczą dotyczącą towarów i usług z tzw. sztywno ustalonego koszyka towarów i usług. 
capita PPP Polski wzrosło do 34 217,716 USD, co oznacza, że realnie Polacy stali się aż 5,54-krotnie bogatsi w porównaniu z rokiem 1990.

W 2019 r. PKB Ukrainy stanowiło 26\% PKB Polski, PKB per capita Ukrainy to $23,7 \%$ PKB Polski per capita, a PKB per capita PPP Ukrainy to 39\% PKB per capita PPP Polski. Tak więc, pomimo że Ukraina w chwili, gdy wchodziła na ścieżkę transformacji ustrojowej, posiadała lepszy niż Polska potencjał ekonomiczny, to po blisko 30 latach od rozpoczęcia przemian politycznych jej gospodarka rozwija się słabiej (biorąc pod uwagę PKB mierzone w USD) niż gospodarka polska, a jej obywatele są zdecydowanie mniej zamożni (biorąc pod uwagę PKB per capita PPP) niż obywatele Polski. Nie powinno zatem dziwić, że Polska staje się państwem coraz bardziej atrakcyjnym ekonomicznie, tak dla obywateli Ukrainy, jak i obywateli innych państw poradzieckich, a także obywateli państw spoza Unii Europejskiej. Jeśli mierzyć atrakcyjność polskiej gospodarki liczbą ogółem wydanych pozwoleń na pracę, to od 2008 r. obserwuje się stały wzrost w tym obszarze. Przykładowo w roku 2008 wydano ogółem 18022 pozwoleń na pracę, w tym dla Ukraińców 5400, a w roku 2019 wydano takich pozwoleń już 444 738, w tym dla obywateli Ukrainy najwięcej, bo aż 330 495. Mniej, bo 27130 (ogółem), pozwoleń na pracę wydano obywatelom Białorusi ${ }^{4}$.

\section{IMIGRANCI ZAROBKOWI (W TYM OBYWATELE UKRAINY) W POLSCE: SYTUACJA SPOŁECZNA}

Analiza danych dotyczących liczby zgłoszonych cudzoziemców do ubezpieczeń społecznych w Polsce w latach 2008-2019 (Mrugała, Nasiński, 2020, s. 9) wskazuje, że w roku 2008 ogółem zgłoszono do ZUS 65041 cudzoziemców, z tego 16350 osób to obywatele Unii Europejskiej. Obywateli krajów spoza UE było 48691 osób, ale samych obywateli Ukrainy - aż 16237 osób, co stanowiło 25,0\% wszystkich cudzoziemców legalnie zatrudnionych w Polce, którzy zostali zarejestrowani w systemie ZUS. Zauważyć jednak trzeba, że grupa obywateli Ukrainy była niemal tak samo liczna jak grupa obywateli państw UE, którzy stanowili 25,1 wszystkich cudzoziemców zgłoszonych do ubezpieczeń społecznych w 2008 r. (Mrugała, Nasiński, 2020, s. 9). Te same dane wskazują, że w roku 2019 liczba wszystkich cudzoziemców zgłoszonych do ubezpieczeń społecznych wynosiła 651506 osób,

4 Analizie poddane opublikowane na stronie Ministerstwa Rozwoju, Pracy i Technologii dane zbiorcze dotyczące liczby wydanych cudzoziemcom zezwoleń na pracę w latach 2008-2019. Dalej w zapisie bibliograficznym jako: Ministerstwa Rozwoju, Pracy i Technologii (2020). 
z tego obywatele Unii Europejskiej to 37596 osób, obywatele krajów spoza UE to 613910 osób, a obywatele Ukrainy to grupa 479113 osób (patrz: Mrugała, Nasiński, 2020, s. 9).

Porównując dane z roku 2019 do danych z roku 2008, trzeba stwierdzić, że ogólna liczba cudzoziemców zgłoszona do ubezpieczeń społecznych powiększyła się dziesięciokrotnie, a liczba obywateli UE - stanowi 2,3-krotny wzrost. Liczba obywateli spoza krajów UE to grupa, która odnotowała 12,6-krotny wzrost, zaś liczba obywateli Ukrainy - to blisko trzydziestokrotny wzrost (dokładnie 29,5-krotny) (Mrugała, Nasiński, 2020, s. 9). Analiza procentowego udziału wymienionych podgrup w grupie pracowników cudzoziemców w Polsce wskazuje, że procentowy udział obywateli UE od roku 2008 do roku 2019 spadł z 25,1\% do 5,8\% i jest to ponad 4-krotny spadek. Obywatele krajów spoza UE, którzy w roku 2008 stanowili 74,9\%, zwiększyli swój udział w grupie ubezpieczonych w ZUS cudzoziemców do 94,2\%. W przypadku obywateli Ukrainy ubezpieczonych w ZUS odnotowano blisko trzykrotny wzrost (Mrugała, Nasiński, 2020, s. 9-10).

Ogólny wzrost liczby ubezpieczonych cudzoziemców w systemie ZUS przełożył się na wzrost tej grupy ubezpieczonych pracowników we wszystkich województwach. W latach 2015-2019 największy liczbowy wzrost ubezpieczonych cudzoziemców odnotowano w województwie pomorskim i warmińsko-mazurskim (był to blisko 5,5-krotny wzrost), najniższy - 2-krotny wzrost - w województwie mazowieckim. Jeśli przeanalizuje się dane liczbowe bezwzględne, to największy przyrost ubezpieczonych cudzoziemców nastąpił w województwach: mazowieckim - wzrost o 101,3 tys. osób; wielkopolskim - wzrost o 50,9 tys. osób; śląskim - wzrost o 44,3 tys. osób i dolnośląskim wzrost o 42,6 tys. osób. Najmniejszy - poniżej 10 tys. osób - wzrost wystąpił w województwach: świętokrzyskim, podlaskim i podkarpackim (Mrugała, Nasiński, 2020, s. 23).

I jeszcze jedna ważna uwaga, która dookreśla wiedzę o sytuacji społecznej ubezpieczonych cudzoziemców w Polsce; otóż, biorąc pod uwagę udział pracowników imigrantów w ogólnej masie wszystkich ubezpieczonych pracowników w Polsce, to - według danych ZUS, przypis za grudzień 2016 r. - stanowili oni 1,5\% ogółu pracowników ubezpieczonych w ZUS, a według przypisu za grudzień 2019 r. - już 3,1\%. Średnia podstawa ich ubezpieczenia wynosiła 2,9 tys. PLN, podczas gdy średnia podstawa ubezpieczenia wszystkich ubezpieczanych w ZUS pracowników wynosiła 3,8 tys. PLN. Średni czas opłacania składek w latach 2017-2019 dla cudzoziemców był niższy niż dla ogółu ubezpieczonych i trwał średnio 6 miesięcy, podczas gdy dla ogółu ubezpieczonych trwał przeciętnie 10 miesięcy (Mrugała, Nasiński, 2020, s. 38). 
Ponadto analiza liczby kont, a także zapisanych na nich tzw. kwot zwaloryzowanego kapitału początkowego i zwaloryzowanych środków na subkontach na koniec 2019 r. wskazuje, że pracownicy cudzoziemcy dysponują łączną liczbą kont w wysokości 2,2 mln, co stanowi 8,3\% ogólnej liczby kont ubezpieczeniowych w ZUS, i zgromadzili oni łącznie na swych kontach i subkontach 18,3 mld PLN, co stanowi tylko 0,60 \% ogólnej kwoty środków zapisanych na kontach i subkontach ubezpieczonych w ZUS (Mrugała, Nasiński, 2020, s. 39).

Swoistym dopełnieniem społecznego obrazu imigracji zarobkowej w Polsce są wnioski pokontrolne, których dostarcza raport Najwyższej Izby Kontroli pt. „Kształcenie dzieci rodziców powracających do kraju oraz dzieci cudzoziemców” opublikowany we wrześniu 2020 r. Autorzy raportu podają - zgodnie z danymi Urzędu do spraw Cudzoziemców - że wzrosła w Polsce także liczba cudzoziemców z zezwoleniem na pobyt stały i czasowy. Zgodnie z danymi na 31 grudnia 2017 r. była to grupa cudzoziemców licząca 294128 osób. Natomiast według danych na 31 lipca 2019 r. liczebność tej grupy cudzoziemców wzrosła do 407 238 osób. Blisko połowę - dokładnie 204113 osób - stanowią obywatele Ukrainy. Jak sugerują autorzy raportu, taki wzrost liczby cudzoziemców z pozwoleniem na pobyt stały lub czasowy musi mieć swoje odbicie w strukturze narodowościowej uczniów w szkole. W grupie uczniów cudzoziemców uczniowie obywatele Ukrainy to grupa licząca 30777 osób (zgodnie z danymi Systemu Informacji Oświatowej na 30 września 2019 r.), co stanowi 74,8\% wszystkich uczniów cudzoziemców (Kształcenie dzieci rodziców powracających do kraju oraz dzieci cudzoziemców, 2020, s. 5). Z danych udostępnionych w raporcie wynika, że w 2015 r. w polskich szkołach uczyło się 9944 cudzoziemców, ale już w roku 2019 liczba ta wzrosła do 41724 osób. Jednocześnie wzrost liczby cudzoziemców w Polsce spowodował także wzrost liczby szkół, do których uczęszczali/uczęszczają uczniowie cudzoziemcy. W roku 2009 takich szkół było 1571, w roku 2019 ich liczba wzrosła do 7318 placówek, co oznacza, że w blisko 1/3 wszystkich polskich szkół uczą się uczniowie cudzoziemcy (Kształcenie dzieci rodziców powracających do kraju oraz dzieci cudzoziemców, 2020, s. 8).

Konkludując, naszkicowana sytuacja społeczna imigrantów zarobkowych w Polsce unaocznia dwie podstawowe kwestie: (1) dynamikę wzrostu populacji imigrantów i (2) dominację obywateli Ukrainy, nie tylko w grupie pracowników cudzoziemców, ale także w grupie uczniów cudzoziemców. Ponadto już pobieżna analiza danych ZUS pozwala uzmysłowić fakt, że imigranci zarobkowi zarabiają ok. 25\% mniej niż ogół ubezpieczonych pracowników, co składania do postawienia dwóch hipotez: (1) imigranci zatrudniani są „,na najniższych” możliwych stawkach płacowych i za taką samą pracę, jaką wykonują Polacy, otrzymują oni mniejsze 
wynagrodzenie; (2) imigranci podejmują niskopłatne prace, które w Polsce nie cieszą się popytem, co znaczyłoby, że cudzoziemcy spychani są na margines zatrudnienia i podejmują pracę, której w Polsce nikt wykonywać nie chce. Za wiarygodnością drugiej hipotezy przemawia fakt, że „program 500+” wszedł w życie w 2016 r. i w tym samym roku niemal podwoiła się liczba wydanych cudzoziemcom zezwoleń na pracę (Ministerstwa Rozwoju, Pracy i Technologii, 2020), a także niemal podwoiła się liczba cudzoziemców zgłoszonych do ubezpieczeń społecznych (Mrugała, Nasiński, 2020, s. 9-10). Jeśli wniosek jest prawdziwy, to wzrost liczby imigrantów zarobkowych został wymuszony polityką społeczną państwa, która spowodowała, że wraz z uruchomieniem „programu 500+” spadł popyt na różnego rodzaju prace niskopłatne/dorywcze/krótkoterminowe, które pozwalały rodzinom najniżej sytuowanym „dorabiać” do domowego budżetu.

Dokonana w tej części artykułu próba opisu społecznej sytuacji imigrantów zarobkowych w Polsce daje wyobrażenie o tym, że wśród tej grupy są samotne osoby i są także rodziny, które zdecydowały się na przyjazd do Polski wraz ze swymi dziećmi. Można zatem ostrożnie postawić kolejne hipotezy: (3) rodziny imigranckie zamierzają pozostać w Polsce na dłużej i po jakimś czasie planują wrócić do kraju pochodzenia; (4) rodziny imigranckie zamierzają pozostać w Polsce na zawsze i z pewnością nie wrócą do kraju pochodzenia; (5) rodziny imigranckie są w Polsce tranzytem, ich docelowym miejscem pobytu może być jeden z krajów Europy Zachodniej, może się jednak zdarzyć, że zostaną w Polsce na dłużej lub na zawsze i z pewnością nie wrócą do kraju pochodzenia; (6) rodziny imigranckie są w Polsce tranzytem, ich docelowym miejscem pobytu jest jeden z krajów Europy Zachodniej, na pewno nie zostaną w Polsce na dłużej i z pewnością nie wrócą do kraju pochodzenia.

Przedstawiony w tej części tekstu opis społecznej kondycji imigrantów zarobkowych, w tym imigrantów obywateli Ukrainy, pozwala - jak wydaje - wyrobić sobie podstawową wiedzę o pracownikach cudzoziemcach w Polsce. Jednocześnie „przywołane liczby” skłaniają do postawienia pytania o to: Kim są ci, którzy za liczbami się skrywają? W żaden sposób nie zamierzam dostarczać całościowej i zobiektywizowanej wiedzy na ten temat, lecz pragnę wpisać się w nurt dyskusji na temat imigracji zarobkowej w Polsce toczącej się w polskich naukach społecznych. Problem wydaje się istotny edukacyjnie, ponieważ - jak uświadamia we wnioskach przywołany wcześniej raport NIK pt. „Kształcenie dzieci...” - polska szkoła nie jest przygotowana do pracy z uczniami cudzoziemcami. Jakościowa część Raportu skłania do namysłu nad wiedzą, którą dysponują dyrektorzy szkół o tej grupie uczniów. Problem wydaje się palący także z tej przyczyny, że polski system ubezpieczeń społecznych „potrzebuje” zatrudnić do 2029 roku aż 5 mln 
pracowników cudzoziemców, aby tzw. współczynnik obciążenia demograficznego pozostał na obecnym poziomie. To oznacza, że w 2029 r. 23\% (co piąta osoba) wszystkich ubezpieczonych w ZUS pracowników stanowiliby cudzoziemcy. Zahamowanie przyrostu współczynnika obciążenia demograficznego o połowę (co w praktyce obniży przyszłe emerytury) wymaga zatrudnienia do 2029 roku 2,2 mln cudzoziemców, co oznacza, że co dziesiąty ubezpieczony w ZUS pracownik byłby imigrantem (Mrugała, Nasiński, 2020, s. 44).

\section{KIM SĄ CI, KTÓRZY SKRYWAJĄ SIĘ ZA LICZBAMI: UWAGI METODOLOGICZNE}

Jako egzemplifikację do dalszego namysłu wybrałam biografię rodziny ukraińskiej - samotnej matki (po rozwodzie) z dwunastoletnim synem - która przyjechała do Polski na cztery lata przed badaniem i tu planuje osiąść na stałe. W 2018 r. na potrzeby książki „Kulturowe konteksty dzieciństwa. Szkice antropologiczno-pedagogiczne” - którą pisałam wspólnie z Anną Młynarczuk-Sokołowską (Kożyczkowska, Młynarczuk-Sokołowska, 2018) - zrealizowałam z rodziną dwa wywiady biograficzno-narracyjne, jeden z dzieckiem, drugi z matką. Interesowały nas wówczas doświadczenia społeczno-kulturowe i językowe dziecka imigrantów zarobkowych, jednak materiał empiryczny okazał się znacznie bogatszy, gdyż w istocie jest to współopowieść o losach współczesnych imigrantów zarobkowych.

Na potrzeby niniejszego artykułu raz jeszcze poddałam analizie uzyskany materiał empiryczny. Tym jednak razem skupiłam się na analizie temporalnej, w wyniku której badałam biograficzne doświadczenie imigracji zarobkowej. Badanie rodzinnej biografii (na którą składały się wspomniane już dwa wywiady) pozwoliło mi zrekonstruować trajektorię imigracji zarobkowej. Jej etapy wyznaczają sytuacje, które swoiście zmieniają bieg życia rodziny wskutek kolejnych wydarzeń społecznych pojawiających się w jej życiu. Jednak to nie fizyczne uczestnictwo w nich jest istotne, lecz generowany poprzez te sytuacje tzw. potencjał trajektoryjny.

Na potencjał trajektoryjny składają się zachowania wymuszone sytuacjami społecznymi - w tym przypadku zawodowymi/zarobkowymi - które powodują/ wytwarzają: określone (czasami dręczące) myśli; określone (czasami silne i ambiwalentne) emocje; nową wiedzę i umiejętności; powodują niewykorzystanie dotychczasowej wiedzy i umiejętności; wymuszają określone postawy społeczne itd. Biograficznie istotne jest przede wszystkim to, że potencjał trajektoryjny to siła sprawcza, która czasami gwałtownie rekonstruuje tor życia człowieka. 
Biograficzne doświadczenie imigracji zarobkowej rozumiane jest przeze mnie jako szczególna odmiana doświadczenia edukacyjnego, które konstruuje to, co za Hannah Arendt nazwać trzeba „kondycją ludzką”. Autorka podkreśla, że ludzie są zależni od świata, jaki wokół siebie tworzą, a tzw. kondycja ludzka konstruuje się w człowieczym działaniu. Teza ta pozwala Hannah Arendt postawić dwa zasadnicze pytania: „Kim jest człowiek?” i „Co człowiek znaczy?”. Logika tak postawionych pytań o człowieka każe przyjąć, że człowiecza egzystencja to nic innego jak działanie, które jest przez człowieka wytwarzane i jednocześnie nie determinuje ono człowieka w sposób ostateczny (Arendt, 2000, s. 14-16). I chociaż działanie jest warunkiem egzystencji, to jest ono także przez egzystencję wytwarzane (Arendt, 2000, s. 19). Oznacza to, że w działaniu i poprzez działanie człowiek może doświadczać siebie i otaczającego świata. W szczególnych sytuacjach działanie nabiera charakteru edukacyjnego, to zaś - jak każde inne doświadczenie - wyrasta z codziennego życia i ujmować je można na co najmniej dwa sposoby: (1) ze względu na jego cel, co wiąże się z owym Arystotelesowskim uznaniem, że ludzie „z natury dążą do poznania” (Arystoteles, 1983, s. 3-4), a samo doświadczenie zaczyna się od zdziwienia, że rzeczy są takie, jakie są (Arystoteles, 1983, s. 9); (2) ze względu na szczególność samego procesu doświadczania, co z kolei odsyła do Gadamerowskiej zasady, w myśl której stare doświadczenie obowiązuje do chwili, w której zostaje ono zakwestionowane przez doświadczenie nowe (Gadamer, 2004, s. 477); jednakże w samej naturze doświadczenia jest to, że jest ono procesem, nad którym się nie panuje, i którego nie można ukierunkować. I jednocześnie, doświadczanie jest procesem, „(...) w którym wszystko porządkuje się w nieprzewidywalny sposób” (Gadamer, 2004, s. 477).

\section{KIM SĄ CI, KTÓRZY SKRYWAJĄ SIĘ ZA LICZBAMI: REKONSTRUKCJA BIOGRAFII IMIGRACJI ZAROBKOWEJ}

Analiza materiału empirycznego pozwala wyłonić pięć zasadniczych etapów biografii zarobkowej/zawodowej rodziny uczestniczącej w badaniu i są to: (1) utrata kontroli nad pracą zarobkową w kraju pochodzenia; (2) poznawcze i emocjonalne oswojenie z decyzją o emigracji zarobkowej; (3) konfrontacja marzeń i oczekiwań z zastaną rzeczywistością w kraju przyjmującym; (4) odzyskanie kontroli nad pracą zarobkową jako odzyskanie kontroli nad życiem; (5) przeniesienie aspiracji zawodowych na drugie pokolenie imigrantów. 


\begin{tabular}{|c|c|c|}
\hline \multirow[t]{4}{*}{1.} & \multirow{4}{*}{$\begin{array}{l}\text { Utrata kontroli } \\
\text { nad pracą } \\
\text { zarobkową } \\
\text { w kraju pocho- } \\
\text { dzenia. }\end{array}$} & $\begin{array}{l}\text { Rozmówczyni (Kobieta/Matka): „(...) nie miałam na Ukrainie możliwo- } \\
\text { ści zmiany swojej pracy”. }\end{array}$ \\
\hline & & $\begin{array}{l}\text { Rozmówczyni (Kobieta/Matka): „Ja zrozumiałam, że nie mam perspek- } \\
\text { tywy, aby coś zmienić”. }\end{array}$ \\
\hline & & Rozmówca (Dziecko/Syn): „(...) mama chciała lepszą pracę”. \\
\hline & & $\begin{array}{l}\text { Rozmówca (Dziecko/Syn): „No chciała [mama - uzupeł. A.K.] pojechać } \\
\text { tutaj i chciała mieć lepszą pracę”. }\end{array}$ \\
\hline \multirow[t]{4}{*}{2.} & \multirow{4}{*}{$\begin{array}{l}\text { Poznawcze } \\
\text { i emocjonalne } \\
\text { oswojenie } \\
\text { z decyzją } \\
\text { o emigracji } \\
\text { zarobkowej. }\end{array}$} & $\begin{array}{l}\text { Rozmówczyni (Kobieta/Matka): „(...) ja zobaczyłam, że tu jest w ogóle } \\
\text { inaczej”. }\end{array}$ \\
\hline & & Rozmówczyni (Kobieta/Matka): „(...) pomyślałam, że dam radę”. \\
\hline & & $\begin{array}{l}\text { Rozmówca (Dziecko/Syn): „(...) nie oswojony, nie wiedziałem jak co } \\
\text { jest, bardzo się bałem rozmawiać z ludźmi, bo to język polski, a ja nie } \\
\text { umiałem wtedy i gadałem tak słabo wtedy”. }\end{array}$ \\
\hline & & $\begin{array}{l}\text { Rozmówca (Dziecko/Syn): „(...) ludzie w Polsce nawet mówią lepiej do } \\
\text { siebie (...)”. }\end{array}$ \\
\hline \multirow[t]{3}{*}{3.} & \multirow{3}{*}{$\begin{array}{l}\text { Konfrontacja } \\
\text { marzeń } \\
\text { i oczekiwań } \\
\text { z zastaną rze- } \\
\text { czywistością } \\
\text { w kraju przyj- } \\
\text { mującym. }\end{array}$} & $\begin{array}{l}\text { Rozmówczyni (Kobieta/Matka): „(...) pewnie to jest nostalgija. Ale ja } \\
\text { nie chcę wracać”. }\end{array}$ \\
\hline & & $\begin{array}{l}\text { Rozmówczyni (Kobieta/Matka): „(...) ja pomyślałam, że ja nie mogę. } \\
\text { Jadę do domu. Oleg* mi mówił, «nie!», «nie!». I nawet taki był moment, } \\
\text { kiedy dziecko płakało, «nie pojadę!»”. }\end{array}$ \\
\hline & & $\begin{array}{l}\text { Rozmówczyni (Kobieta/Matka): „(...) on mówi, że chce do domu. Ja } \\
\text { mówię «Oleg, no co ty... my tu przyjechaliśmy, tyle już włożyliśmy } \\
\text { w to, bo ty języka się uczysz. I co? Pojedziemy teraz do domu? Dawaj! } \\
\text { Spróbujemy!»”. }\end{array}$ \\
\hline
\end{tabular}

4. Odzyskanie Rozmówczyni (Kobieta/Matka: „Mam nadzieję, że coś mogę zmienić kontroli nad (...).

pracą zarob- $\quad$ Rozmówczyni (Kobieta/Matka): „Nawet mam wielu ludzi wokół siebie kową jako odzyskanie kontroli nad (...)” życiem.

Rozmówca (Dziecko/Syn): „(...) po prostu pytam się mamy (...)”. Rozmówca (Dziecko/Syn): „Robiłem co robili inni. Mówiłem, co mówili inni”.

5. Przeniesienie Rozmówczyni (Kobieta/Matka): „Bo rozumiem, że jest tu perspektywa aspiracji dla dziecka”.

zawodowych Rozmówczyni (Kobieta/Matka): „«Ty rozumiesz, że masz głowę i musisz na drugie pokolenie imigrantów. się uczyć!»”.

Rozmówca (Dziecko/Syn): „Chciałbym zostać w Polsce”.

Rozmówca (Dziecko/Syn): „(...) Mama bardzo mnie pilnuje, żebym miał dobre oceny”.

Rozmówca (Dziecko/Syn): „(...) nauczyć się tak idealnie polskiego języka, ale żeby mieć też dobrą pracę, trzeba znać angielski”.

* Imię dziecka zostało zmienione.

Źródło: opracowanie własne 


\section{AD.1. Utrata kontroli nad pracą zarobkową w kraju pochodzenia}

Dostęp do dobrych miejsc pracy i związany z tym prestiż, jaki dana praca buduje w świadomości społecznej, mają swoje odzwierciedlenie w odczuwanej przez człowieka satysfakcji z pracy zarobkowej, a także w zadowoleniu, że wykonywana praca przynosi nie tylko gratyfikacje finansowe, ale cieszy się także uznaniem innych. Jeśli w jakieś dużej części - a przynajmniej w części związanej z wynagrodzeniem za pracę - człowiek nie doświadcza tego wszystkiego, to - jak pokazują doświadczenia społeczne rozmówczyni biorącej udział w badaniu - stopniowo rozwija się syndrom chronicznego stresu psychologicznego.

Analiza treści wywiadów pozwala rozpoznać, jak kobieta i jej syn przeżywali fakt, że praca zarobkowa na Ukrainie przestała zaspokajać bytowe potrzeby ich rodziny. W tej sprawie szczególnie uciążliwe było to, że realizowana praca nie zaspokajała także potrzeb psychicznych i społecznych rozmówczyni. Cała ta psychiczno-społeczna sytuacja związana z wykonywaną pracą zarobkową powodowała silną potrzebę zmiany zajęcia, ale niemożliwość znalezienia lepszej pracy powodowała ciągłe narastanie dyskomfortu poznawczo-emocjonalnego. W efekcie nie tyle zła praca - w sensie ekonomicznym, psychicznym i społecznych - ile niemożność jej zmiany poszerzała i pogłębiała stres psychologiczny. Doświadczana na tym polu bezsilność przekłada się na przywołane w tabeli 1 stwierdzenie „nie miałam na Ukrainie możliwości zmiany swojej pracy”.

Rozmówczyni (Kobieta/Matka): (...) nie miałam na Ukrainie możliwości zmiany swojej pracy. Nie chciałam iść do szkoły [uczyć - uzupeł. A.K.], ponieważ... na początku chciałam [uczyć - uzupeł. A.K.], ale zawsze obok mnie byli nauczyciele i ja widziałam jakie problemy przynosi ta praca. A u nas jest taka trudność... bo nieważne, że człowiek dobrze pracuje, i że jest lubiany przez dzieci. Ale najważniejsze to są papiery, żeby wszystko było w papierach zrobione, czyli napisane. I mama zawsze mi mówiła: dziecko, ty nie wytrzymujesz tego, twoje nerwy tego nie wytrzymują. I nie poszłam pracować do szkoły, ale zostałam... najwięcej pracowałam w sklepach, trochę w bibliotece i takie różne rzeczy robiłam. Zrozumiałam, że muszę nauczyć się takiego biurowego stylu pracy, na komputerze... Nie było jednak takiej pracy. Mam taką fajną koleżankę, która miała swoją firmę, współpracuje i z firmami z Polski i z Niemiec (...) i mówiłam jej, nie chcę pracować w sklepie. Myślałam, że może ona mi coś innego zaproponuje. A ona mi powiedziała, że chyba sprzątanie... Ja byłam w szoku. To ja jestem nauczycielką, ja nie jestem głupia! Ja mam iść sprzątać? I ty jesteś moją koleżanką? To ja tak zrozumiałam.... i inne różne były podobne sytuacje... Ja zrozumiałam, że 
nie mam perspektywy, aby coś zmienić. I w ogóle, teraz my mamy u nas w kraju tak, że jest jeden handel. Sprzedajemy. Kupujemy i sprzedajemy. Nie ma jakiegoś innego wyboru. No są jakieś tam fabryki..., ale tam jest bardzo mało pracy... To jest w chemii... To jest... No to jest takie trudne... to coś, z czego my możemy wybierać tą pracę, ale mi to nie odpowiada.

Na ten sam aspekt zwraca uwagę syn rozmówczyni, który tak mówi:

Rozmówca (Dziecko/Syn): Mieszkaliśmy na Ukrainie. I na Ukrainie jest ciężko znaleźć pracę, jakby taką dobrą, żeby się dobrze zarabiało. I żeby mieć pieniądze. (...) I mama chciała lepszą pracę, bo pracowała w sklepie i tam było dużo takich...pijących ludzi, którzy ją... byli... jakby to powiedzieć, źli dla niej. No i mama nie chciała już więcej tego słuchać. No chciała pojechać tutaj i chciała mieć lepszą pracę.

\section{AD. 2.: Poznawcze i emocjonalne oswojenie z decyzją o emigracji zarobkowej} Ten etap życia bezpośrednio poprzedza fizyczną emigrację i jego celem jest przygotowanie do wyjazdu poprzez uczenie się języka we własnym zakresie („Powoli zaczęliśmy się jakby przygotowywać do tego, dziecko moje chodziło na kursy polskiego języka. I tak trochę... ja też zaczęłam trochę czytać, uczyć się liter, żeby tak nie przyjechać i nic nie wiedzieć”) i gromadzenia wiedzy o państwie/regionie, do którego planuje się wyemigrować. Ważną częścią takiego przygotowania jest zorganizowanie pierwszej pracy, która pozwoli utrzymać się w kraju przyjmującym. Drugim istotnym elementem są ludzie, na których będzie można wesprzeć się przynajmniej w pierwszym etapie życia na emigracji, czyli wtedy, gdy poziom znajomości języka kraju emigracji nie pozwala na samodzielność. Rozmówczyni mówi wprost o tym okresie życia:

A.K.: Nie bała się pani przyjechać do Polski?

Rozmówczyni (Kobieta/Matka): Nie... no mam tu siostrę! I pomyślałam, że jakieś tam oparcie mam, żeby coś tam załatwić..., (...) powiedzieć, zrobić, co trzeba było, iść do urzędu. I teraz ja rozumiem, tyle ludzi ma problemy, bo oni nie rozumieją i nie mogą powiedzieć. Często jest tak, że jak ty nie rozumiesz, no to do widzenia. No nie możemy przyjechać i gadać tu po polsku. I to takie było nieprzyjemnie i teraz rozumiem, jak dobrze, że mam siostrę. Bo pewnie, że gdyby nie było siostry, ja z dzieckiem bym tu nie przyjechała. Bo to jest bardzo ryzykowne. No. I takich fajnych ludzi mamy, że była taka pomoc na początku i z mieszkaniem, i z tą pracą, że ja tu byłam - dwa lata tak od czasu 
do czasu przyjeżdżałam. Ja już widziałam ludzi i coś mogłam załatwić z pracą codzienną Ale coś było, jakiś początek z tego był. I pomyślałam, że dam radę.

Przygotowania, które podjęła rozmówczyni, nie zaskakują, gdyż są właściwym działaniem dla tego etapu emigracji. Uwagę zwraca praca umysłowa związana z „oswojeniem” kraju przyjmującego w świadomości rozmówców poprzez skonstruowanie szczególnej narracji, której celem jest wytworzenie poznawczo-emocjonalnego stosunku do kraju emigracji, co sprowadza się do uznania, że w Polsce jest „bardzo fajnie”. Zwracają na to uwagę wypowiedzi chłopca, który mówi wprost o „oswojeniu” i podkreśla, że w Polsce jest „bardzo fajnie”, wszystko w niej jest „ładne”, jest w niej „czyściej jakby” i nawet ludzie w tym kraju są „lepsi niż na Ukrainie” i „nawet mówią lepiej do siebie”.

A.K.: Gdy przyjechałeś pierwszy raz do Polski, wtedy zimą, zobaczyć jak tu jest, to co sobie wtedy myślałeś o Polsce?

Rozmówca (Dziecko/Syn): No myślałem, że jest tutaj bardzo fajnie. Ładnie tutaj jest. No wtedy nie poszedłem do szkoły, to nie mogę nic powiedzieć o dzieciach jakie są. Ale głównie miałem dobre myśli o Polsce.

A.K.: A co ci się najbardziej spodobało?

Rozmówca (Dziecko/Syn): Najbardziej mi się spodobało Stare Miasto na przykład, że tutaj jest tak ładnie. Morze mi się spodobało. Spodobało się, raczej to, że tutaj w Gdańsku jest tak czyściej jakby. Ludzie są lepsi niż na Ukrainie, bo na Ukrainie... no... nie wszyscy są źli. 40\%. Raczej mniejsza część to są tacy ludzie niedobrzy. No w Polsce, to jakieś $20 \%$.

A.K.: Jak myślisz, dlaczego to jest tak, że w Polsce tylko 20\% ludzi jest złych, a na Ukrainie aż $40 \%$ ?

Rozmówca (Dziecko/Syn): Nie wiem.... No na przykład... ludzie w Polsce nawet mówią lepiej do siebie. Nie tak jak na Ukrainie (...), ci którzy są... jesteś z Polski, albo z Rosji, to jesteś zły. Jesteś za kimś i jesteś taki zły i nikt nie chce cię. A tutaj w Polsce, tak nie mówią. Nawet ja jestem z Ukrainy i mnie dobrze przyjęli w szkole.

(...)

A.K.: A jak to było, gdy za drugim razem przyjechałeś? Jak wtedy widziałeś Polskę?

Rozmówca (Dziecko/Syn): No, widziałem już tak trochę... jakby bardziej oswojony już... już mniej chciałem jechać na Stare Miasto, już widziałem tam wszystko. I... no nie wiem...

A.K.: Za pierwszym razem nie byłeś oswojony? 
Rozmówca (Dziecko/Syn): Za pierwszym razem nie.

A.K.: To jaki byłeś?

Rozmówca (Dziecko/Syn): No, nie oswojony, nie wiedziałem jak co jest, bardzo się bałem rozmawiać z ludźmi, bo to język polski, a ja nie umiałem wtedy i gadałem tak słabo wtedy.

Wykonana praca świadomościowa obiektywizuje się w zdaniu: „głównie miałem dobre myśli o Polsce”. Wytworzona narracja - niemal na miarę „,szklanych domów” Stefana Żeromskiego - wydaje się mieć tylko dwa cele: (1) utrzymać w mocy decyzję o wyjedźcie z kraju poprzez jej legitymizowanie pozytywnymi „faktami” o kraju emigracji; (2) podtrzymywać motywację do pozostania w kraju emigracji, szczególnie wtedy, gdy pojawią się i napiętrzą trudności.

Drugi aspekt jest dostrzegalny dopiero z perspektywy czasu; w wypowiedziach rozmówców rozpoznać można ciągle obecną fascynację Polską. Jest w ich wypowiedziach ekscytacja wynikająca z nadziei na lepsze życie, a nadzieja ta wynika z tego, że „teraz” mają oni wpływ na swoje teraźniejsze i przyszłe życie. Nadzieja jest konstruowana na fundamencie tej pierwszej świadomościowej pracy, która została wykonana jeszcze na Ukrainie, gdyż to wtedy „urodziło się” przekonanie, że w Polsce jest inaczej, a pobyt w Polsce dzień po dniu utwierdza rozmówców w prawdziwości narracji, gdyż ma ona odzwierciedlenie w tym, co widzą oni dookoła siebie, a co zamyka się w zdaniu: „A teraz ja zobaczyłam, że tu jest w ogóle inaczej”:

Rozmówczyni (Kobieta/Matka): (...) A teraz ja zobaczyłam, że tu jest w ogóle inaczej: człowiek - ja nie wiem, czy jest takie słowo - szanuje jeden drugiego (...), bo u nas takie słabe jest pojęcie o tym. I to było bardzo miłe. Przyjemnie, że tu jest inaczej. I nawet, ci cudzy ludzie inaczej z sobą rozmawiają (...) i tak wszystko inaczej wygląda. Wygląda wszystko lepiej. To pierwsze, czym ja byłam zdziwiona. I porządek. Teraz u nas... ta strona bliżej Polski... tam też ludzie starają się ogarnąć domy, żeby było fajnie. Jakieś kwiaty. Takie rzeczy, ale one cieszą oko. Bo tam dalej do nas, jak na wschód się jedzie, no to tam jest strasznie. Takie... nie jest... no ludzie myślą, że to jest normalne, coś tam stare... żeby było... coś tam zjeść... praca, nie praca... nie chcę mówić... wódka... jakoś więcej w tej stronie. U nas [w zachodniej Ukrainie - uzupeł. A.K.] tak..., może dlatego, że my bliżej tu jesteśmy, to my tak ciągniemy do jakiejś kultury, czegoś takiego fajnego. I było mi przyjemnie, że jest tu tak fajnie. I trawa jest skoszona. Trochę drogi - tam jest miejscami, gdy jedziemy jest trochę inaczej, nie bardzo fajnie - bo tu w Gdańsku to jest 
super! [śmiech] (...). Bo u nas bardzo słabo... z drogami! No i pewnie to takie było pierwsze wrażenie. I że każdy dom jest taki piękny, ogarnięty. I tak wygląda fajnie. U nas nie zawsze tak jest.

\section{AD. 3.: Konfrontacja marzeń i oczekiwań z zastaną rzeczywistością w kraju przyjmującym}

Powyższy cytat pozwala dostrzec jeszcze inny element konstruowanej narracji, a mianowicie, w świadomości rozmówczyni, dzisiejsza Ukraina to państwo złożone z dwóch światów, Zachodu i Wschodu. Zachodnia Ukraina zamieszkana jest przez ludzi, którzy „ciągną do kultury”, do czegoś co jest „fajne” i „piękne”, gdyż w takim świecie ludziom jest przyjemnie żyć. We Wschodniej Ukrainie jest zupełnie inaczej, co sprowadzić można o twierdzenia, że jest tam jakby mniej kultury. Nie powinno zatem nikogo dziwić, że niektórych - czyli tych, którzy mieszkają w zachodniej części Ukrainy - „ciągnie do jakiejś kultury, do czegoś fajnego”. Jak się wydaje, można to znaleźć w Polsce, a właściwie w niektórych - fajnych, pięknych i historycznych - jej regionach. Wszystko to składa się na fenomen „miodowego miesiąca” (Kożyczkowska, Młynarczuk-Sokołowska, 2018, s. 61. Barzykowski, Grzymała-Moszczyńska, Dzida i in., 2013, s. 75), który w badanej biografii rodziny ukraińskiej rozpoczyna się jeszcze przed wyjazdem do Polski. Sporadyczne odwiedziny w Polsce potwierdzały raz po raz fantastyczność tego kraju, tak w świadomości matki, jak i syna, i wzmacniały ekscytację tym innym, kulturalnym i historycznym państwem.

Początek życia na emigracji to wejście w rolę imigranta zarobkowego, który musi borykać się z wieloma problemami, a ich waga i kłopotliwość wynika w początkowej fazie - głównie ze słabej znajomości języka. Opisywany w literaturze przedmiotu „negatywny szok kulturowy” (więcej: Boski, 2009, s. 522-541. Barzykowski, Grzymała-Moszczyńska, Dzida i in., 2013, s. 75) ujawnia się także w doświadczeniach rozmówców i w dużej mierze wynika z konieczności rozwiązywania codziennych problemów, takich jak - przykładowo - realizacja obowiązku szkolnego przez chłopca, znalezienie dodatkowej pracy, poszukiwanie mieszkania itd. Jednak - jak wynika z opowieści matki i syna - ta rozwinięta wcześniej fascynacja Polską i ekscytacja możliwością życia w Polsce, w jakiś szczególny (magiczny?) sposób pozwoliła rodzinie przetrwać ten trudny czas, w którym rozwija się to, co kobieta nazywa „nostalgiją”.

Rozmówczyni (Kobieta/Matka): No i to.. ciężko mi jest i ja cieszę się, że tu jestem. Ale jestem tu, ale tam jest moja... tam jest mój dom tak jakby i ja lubię ten kraj. Ja lubię swoją rodzinę. W ogóle lubię swoją przyrodę, bo ona 
tak trochę inna. To jest piękne... tylko pewnie to jest nostalgija. Ale ja nie chcę wracać. Mam różne problemy, bo to i pieniądze, i praca... może nie jest tak łatwo. No, ale ja mam nadzieję, że coś zmienię. Jest ważny taki moment, że... ja rozumiem, że na Ukrainie nie miałam możliwości zmienić swojej pracy.

Szczególność tej fazy polega na tym, że każda, nawet zwyczajna sytuacja społeczna - jak zmiana szkoły dziecka czy znalezienie dodatkowej pracy - staje się sytuacją eskalującą stres psychologiczny. Wymienione sprawy nie są oczywiście łatwe i proste, ale zwykle ludzie całkiem dobrze radzą sobie w ich rozwiązywaniu. Jednak, jak dowodzą doświadczenia kobiety, w przypadku imigrantów zarobkowych, którzy słabo znają język kraju pobytu, takie „zwykłe” zdarzenia mogą być rozpoznawane jako te, które są ponad siłę człowieka. Sprzyja to rozwojowi stresu psychologicznego (Lazarus, 1998, s. 182-219; Lazarus, 1993, s. 1-21), którego punkt ciężkości spoczywa na poznawczej ocenie sytuacji.

W badanej biografii rodziny imigranckiej szczególnie interesujący jest fenomen wzajemnego wsparcia, którego udzielają sobie matka i syn. Raz syn „wywiera psychiczną presję” na matce, aby zostać, walczyć i nie wracać na Ukrainę, innym razem to matka jest źródłem wsparcia dla swego dziecka. Przykładem może być tu wypowiedź rozmówczyni:

Rozmówczyni (Kobieta/Matka): I miałam bardzo różne problemy z tymi dokumentami, bo to to im nie pasuje. To te..., oni nie chcą. I szef mój też tak nie bardzo chciał to wszystko załatwić. I dużo razy byłam... ja pomyślałam, że ja nie mogę. Jadę do domu. Oleg ${ }^{5}$ mi mówił, „nie!”, „nie!”. I nawet taki był moment, kiedy dziecko płakało, „nie pojadę!”. „Mamo, ja cię proszę! Nie pojadę! Ja nie chcę!”.

\section{AD. 4.: Odzyskanie kontroli nad pracą zarobkową jako odzyskanie kontroli nad życiem}

Odzyskanie poczucia sprawstwa nad pracą w badanej biografii związane jest z awansem zawodowym, który polegał na tym, że kobieta została przeniesiona/ /przeszła do pracy biurowej przy komputerze. Jej kompetencja językowa była już na tyle wysoka, że mogła ona swobodnie wchodzić w relacje komunikacyjne, co zwrotnie dostarczyło edukacyjnych okazji do pogłębiania sprawności językowych dla języka polskiego. Co istotne, kobieta w relacjach z polskimi współpracowni-

\footnotetext{
${ }^{5}$ Imię dziecka zostało zmienione.
} 
kami stała się bardziej otwarta i odważna, nie bała się też prosić o naukę języka, gdyż była/jest świadoma ciągle zbyt słabej znajomości języka polskiego. Dobrze oddają to słowa:

Rozmówczyni (Kobieta/Matka): Ale ja nie mogę tak szybko, bo mam problem z językiem, ale powoli ogarniałam to, ale wiem, że ja nie zawsze mówię dobrze. Też i z komputerem teraz pracujemy, teraz mamy inny system (...). On jest taki bardzo ciężki, ale myślę, że dam radę. No i podoba mi się tu, że... ja czuję jest różnica (...).

Aby lepiej zrozumieć ten etap biografii, warto prześledzić dziejące się doświadczenie nadziei, do którego w swojej opowieści rozmówczyni wprost odwołuje się dwukrotnie: „(...) mam nadzieję, że coś zmienię” i „(...) teraz ja mam nadzieję, że ja mam możliwość, aby coś zmienić”. Śledząc biograficznie konstruowane doświadczenie nadziei w wypowiedzi rozmówczyni, rozpoznać można moment, w którym odzyskuje ona poczucie kontroli nad obszarem pracy zarobkowej, to zaś konstruuje w jej świadomości przekonanie o stabilizacji finansowej i poczucie bezpieczeństwa socjalnego.

Odzyskanie poczucia mocy i sprawstwa w obszarze pracy związane jest z dekonstrukcją jej poznawczo-emocjonalnego stosunku do otaczającego świata. Z tego procesu wyłania się obraz własnej osoby, w którym kobieta staje się coraz bardziej pewna siebie, gdyż dowody własnej skuteczności odnajduje we własnym działaniu w otaczającym ją świecie. Doświadczane w tym etapie biograficznym poczucie sprawstwa jest jej psychicznym oparciem w codzienności. Równocześnie w większym stopniu rozmówczyni staje się podporą dla swojego syna, o czym tak mówi:

Rozmówczyni (Kobieta/Matka): Mam nadzieję, że coś mogę zmienić, bo teraz ja mogę czytać, zrozumieć, że coś jemu [dziecku - uzupeł. A.K.] poradzić. Zapytać [mogę syna - uzupeł. A.K.] co wiesz, czego nie wiesz i to jakoś ogarnąć, bo na początku moi koledzy się tym zajmowali. Czytałam bardzo słabo i połowy z tego nie rozumiałam... w ogóle nie rozumiałam o co chodzi. Siostra to... to jak miała czas, to też ogarniała. Teraz mnie cieszy, że ja coś jeszcze mogę.

Osiągnięta w rodzinie równowaga psychiczna powoduje, że rozmówczyni może tym samym zapewnić swemu dziecku większe bezpieczeństwo emocjonalne i poznawcze, dzięki czemu chłopiec nie musi już tak bardzo „martwić się o mamę”. Dziecko może więc angażować się w zwyczajne sprawy nastolatków. Osiągnięta 
w rodzinie równowaga powoduje, że dziecko świadomie zaczyna kierować uwagę na sprawy kultury polskiej - jej historię, tradycję, język (i jego gramatykę) itd. Docierają też do niego znaczenia i waga różnic kulturowych ukraińsko-polskich. W konfrontacji z różnicą kulturową radzi sobie na trzy sposoby: (1) jest bierny i wyczekuje na rozwój wypadków („,...) nic nie robiłem. Po prostu czekałem (...)”); (2) naśladuje zachowania rówieśników w nowych dla siebie sytuacjach („Robiłem co robili inni. Mówiłem, co mówili inni (...)”); (3) zasięga porad matki, którą uznaje za ekspertkę od tego typu spraw („Po prostu pytam się mamy, czy nie muszę robić, czego nie mogę robić, a co mogę robić”).

\section{AD. 5.: Przeniesienie aspiracji zawodowych na drugie pokolenie imigrantów}

Ta faza biografii nie zaczyna się nagle i ma ona swoje zapowiedzi, które rozpoznać można jako rodzącą się świadomość konieczności emigracji zarobkowej. Dobrze obrazują to słowa rozmówczyni:

Rozmówczyni (Kobieta/Matka): Byłam tu [w Polsce - uzupeł. A.K.] parę razy i zrozumiałam, że muszę to zrobić [wyemigrować - uzupeł. A.K.]. I dla siebie, i dla dziecka. No najpierw dla dziecka. Bo rozumiem, że jest tu perspektywa dla dziecka. I mamy tu koleżankę, która skończyła tu studia. Ona jest prawnikiem i pracuje w fajnej firmie. No! Jest szansa coś zmienić w swoim życiu i jakoś inaczej, lepiej żyć. A rozumiem, że chłopak ma głowę, coś może jeśli chce!

Jeśli powyższą wypowiedź kobiety uzupełnić wcześniej przytoczonymi zdaniami z jej narracji: „zrozumiałam, że nie mam perspektywy, aby coś zmienić” i „na Ukrainie nie miałam możliwości zmienić swojej pracy”, to uchwycić można istotę tego, jak subiektywnie rozmówczyni oceniała własne położenie w kraju pochodzenia. Obrazowana w słowach kobiety beznadzieja własnego życia zdaje się także - w jej odczuciu - tym, co czeka jej syna. Analiza wypowiedzi wskazuje, że - jako pracownica - nie miała ona wygórowanych ambicji, chciała tylko zwyczajnie pracować przy komputerze i wykonywać pracę biurową.

Te aspiracje zostały zrealizowane w Polsce (w chwili badania taką właśnie pracę rozmówczyni wykonuje). Zgromadzony materiał nie pozwala stwierdzić, czy będąc teraz w Polsce, kobieta marzy o lepszej pracy niż zatrudnienie w biurze magazynu urządzeń technicznych. Być może w przyszłości uzupełni wykształcenie, aby - przykładowo - podjąć bardziej wymagającą pracę, w wyniku której nie tylko zwiększy własne wynagrodzenie, ale być może doświadczy także większej satysfakcji zawodowej. 
Rodzina podjęła decyzję o pozostaniu w Polsce na stałe i zaczęła w związku z tym zamykać ostatecznie swoje sprawy na Ukrainie („teraz właśnie sprzedajemy to mieszkanie” - jak mówi chłopiec podczas wywiadu) i - jak się wydaje - nie zamierza też emigrować do któregoś z krajów Europy Zachodniej. Treści obu wywiadów wskazują, że matka i syn są świadomi tego, że ich kapitałem jest dobra znajomość języka polskiego, formalne wykształcenie i posiadana wiedza. Stąd nacisk na edukację syna jeszcze przed wyjazdem z Ukrainy („moje dziecko chodziło na kursy polskiego języka”) i troska o to, aby syn dobrze się uczył w Polsce. Przykładem mogą być dwie wypowiedzi - syna i matki:

Rozmówca (Dziecko/Syn): (...) Mama bardzo mnie pilnuje, żebym miał dobre oceny, zawsze wchodzi do Internetu, żeby zobaczyć jakie ja mam oceny.

Rozmówczyni (Kobieta/Matka): No ja mówię do niego: „To nie jest tak ważne! [chodzi o relacje z rówieśnikami - uwaga A.K.]. Najważniejsze jest to, że ty masz wszystko wiedzieć! Chodzić na lekcje, widzieć nauczyciela, słyszeć, rozumieć, odrabiać w domu lekcje i żeby to było porządnie. Ty rozumiesz, że masz głowę i musisz się uczyć!”

Analiza wywiadów pokazuje, że ścieżka kształcenia chłopca wstępnie została naszkicowana jeszcze przed wyjazdem z Ukrainy, o czym świadczy wypowiedź dziecka: „I ciocia pojechała właśnie do Gdańska uczyć się... no i mówiła żebyśmy tutaj przyjeżdżali, żebym tutaj się uczył, żebym też poszedł na Uniwersytet potem”. Sama rozmówczyni niewiele mówi na temat przyszłości swojego syna, ale wypowiedzi chłopca sugerują, że rozmyśla on na ten temat i że - być może - takie rozmowy toczą się w rodzinie. Chłopiec zapytany o to, czy chciałby wrócić na Ukrainę, czy pozostać w Polsce na stałe, mówi:

Rozmówca (Dziecko/Syn): Chciałbym zostać w Polsce.

AK: A co chciałbyś robić w Polsce, w przyszłości?

Rozmówca (Dziecko/Syn): Tak naprawdę nad tym jeszcze nie myślałem, bo jakby... ciężko powiedzieć jaki chciałbym mieć zawód. Chciałbym jakiegoś łatwiejszego, no żeby to nie była praca fizyczna, bo zazwyczaj za pracę fizyczną dostaje się mniej. I pracujesz ciężej. No i chce się, żeby tylko pracować głową i dostawać więcej pieniędzy. I... nie wiem...

AK: I jaką pracę chciałbyś wykonywać? Umysłową? Tak?

Rozmówca (Dziecko/Syn): No na przykład chciałbym być inżynierem... (...) 
AK: Powiedz, czy coś trzeba szczególnego zrobić, żeby zostać w Polsce na stałe?

Rozmówca (Dziecko/Syn): Myślę, że nauczyć się tak idealnie polskiego języka, ale żeby mieć też dobrą pracę, trzeba znać angielski. No, ja na przykład teraz znam trzy języki: polski, ukraiński i rosyjski. Ale.. no i właśnie mogą się przydać. Rosyjski nawet, bo mogę rozmawiać np. w Białorusi po rosyjsku, kiedy może tam pojadę. No właśnie tak to się przyda. Po angielsku mogę rozmawiać wszędzie, bo to jest język międzynarodowy.

AK: A czy coś jeszcze trzeba zrobić, by zostać na stałe?

Rozmówca (Dziecko/Syn): ummm.. no... nie wiem... mi się wydaje, że nie.

Cena, którą chłopiec „musi zapłacić” za to, aby pozostać w Polsce na stałe, jest jednak wysoka. Analiza wypowiedzi chłopca, która została szczegółowo przedstawiona w książce „Kulturowe konteksty dzieciństwa...” (patrz: Kożyczkowska, Młynarczuk-Sokołowska, 2018, s. 113-140), ukazuje nie tylko to, w jaki sposób język ojczysty dziecka traci na znaczeniu w jego świadomości, a język kraju emigracji zyskuje na znaczeniu, uzmysławia ona także tempo, w jakim zachodzi ten proces. W ciągu czterech lat pobytu w Polsce w świadomości chłopca język ukraiński pod względem prestiżu przesunął się na czwarte miejsce: po języku polskim, angielskim i rosyjskim. A chłopiec nie chce uczyć się języka ukraińskiego nawet gdyby zorganizowano takie lekcje, bo jest to wyłącznie język domu. Ukraiński jest używany tylko w otoczeniu rodziny ukraińskiej, bo w obecności polskich gości domownicy przechodzą na język polski. Ewentualnie - jak chłopiec sam mówi - języka ukraińskiego będzie go uczyła babcia podczas wakacji spędzanych na Ukrainie, lecz w ciągu czterech lat (od przyjazdu do Polski do chwili uczestniczenia w badaniach) nie był on na Ukrainie. Na nauce języka ukraińskiego zależy jednak matce chłopca, gdyż tylko tak może on zachować swoją ukraińskość.

AK: Chciałaby pani, aby pani dziecko chodziło na język ukraiński?

Rozmówczyni (Kobieta/Matka): No tak. Żeby była możliwość. Pewnie. On to mówi „po co mi ukraiński?”. Ja: „dziecko, co ty gadasz? Jesteśmy w Polsce, wszystko pięknie, ale jesteś Ukraińcem. Ty jesteś narodem, który ma ten język pamiętać i trzymać go. Nie będziemy znać ukraińskiego i nie będzie ukraińskiego narodu. No co ty!”. On nie chce. Ja mam nadzieję, że babcia to ogarnie.

Jak mówi matka, chłopiec nie chce uczyć się języka ukraińskiego. Można ostrożnie uznać, że w dużej mierze jest to efekt społecznego uczenia, w wyniku 
którego dziecko okryło klucz do sukcesu: musi stać się Polakiem poprzez mówienie i zachowanie. Zasada ta została odkryta przez chłopca bardzo wcześnie, bo podczas pierwszej wigilii szkolnej, w pierwszym roku pobytu w Polsce. Nie mając znikąd pomocy, dziecko - aby przetrwać jako obce w świecie swoich - musiało zwyczajnie stać się podobne do dzieci polskich. Owo: „Robić, co robią inni. Mówić, co mówią inni” okazało się skuteczne. W późniejszym okresie pobytu chłopiec przekonuje się, że poza kilkoma obszarami - jak np. religia i religijność - ludzie właściwie zachowują się podobnie, a grono jego polskich rówieśników (przyjaciół i kolegów ze szkoły) zajmuje się właściwie tymi samymi sprawami, jakimi zajmowali się jego ukraińscy rówieśnicy.

Tak więc, aby pozostać w Polsce, chłopiec musi „idealnie nauczyć się języka polskiego”, musi dobrze się uczyć, pójść na uniwersytet i zostać inżynierem. Wobec takiej przyszłości - choć dopiero szkicowanej, to już dość skonkretyzowanej - chłopiec nie chce wracać na Ukrainę, ani teraz w dzieciństwie, ani później w dorosłości:

AK: Co musiałby się stać, abyś chciał wrócić na Ukrainę? Co musiałoby się zmienić, abyś chciał spędzić swoją dorosłość na Ukrainie, a nie w Polsce?

Rozmówca (Dziecko/Syn): [dłuższa pauza] Nie wiem... my nie mieszkaliśmy tam, gdzie była wojna. Wszystko było dobrze. (...) jak to powiedzieć?... może warunek, przez który przyjechaliśmy do Polski. To były drogie produkty, tam na przykład... no mama dobrze zarabiała w tym sklepie, nam wystarczało, dużo wystarczało. Mieliśmy swój..., swoje mieszkanie, w dobrym rejonie, i teraz właśnie sprzedajemy to mieszkanie. I po prostu zmieniły się te ceny, i tak zaczęło nam brakować tych pieniędzy. No i właśnie pojechaliśmy tutaj do Polski, i tutaj tak jakby jest... na Ukrainie jest tak, że ile się zarabia, to większą część wydaje się na jedzenie. I na... na produkty. A w Polsce, jakby zarabia się więcej, i produkty kosztują czasami tak samo, czasami trochę taniej, a czasami trochę drożej. Zależy od produktu...

AK: Ale mniej się wydaje, tak w całej masie, na jedzenie i produkty w Polsce?... Rozmówca (Dziecko/Syn): Tak!...

AK: To znaczy, że w Polsce więcej pieniędzy wobec tego zostaje?

Rozmówca (Dziecko/Syn): Tak!

AK: Czy gdyby na Ukrainie była taka sama sytuacja jak ta w Polsce, o której mówisz to..., to czy byłby to warunek, że mógłbyś wrócić jako dorosły na Ukrainę?

Rozmówca (Dziecko/Syn): Raczej by to nie był, tylko jeden taki warunek, raczej by jeszcze... (...) no wiem... raczej nic by się nie stało, żebym wrócił 
na Ukrainę. Bo nie chcę wracać na Ukrainę. I... no bardzo bym chciał, żeby jeszcze moja druga ciocia przyjechała tutaj z moim wujkiem i kuzynką. Tutaj do Polski. Razem z babcią. Żebyśmy wszyscy tu byli w Polsce. Żebyśmy nie mieszkali tam na Ukrainie. Ale... raczej nie pojadą tutaj, bo mój wujek tam dobrze zarabia; on jest dyrektorem firmy. I właśnie dobrze zarabiają, mają tam dom i jest im tam lepiej. I moja kuzynka nie chce jechać do Polski na stałe, tylko tak odwiedzić nas.

\section{KIM SA IMIGRANCI ZAROBKOWI? I CO ONI ZNACZĄ? PRÓBA PODSUMOWANIA}

Transformacja ustrojowa - jak o tym pisałam we wprowadzeniu - miała swoje oparcie w ekonomii i wszelkimi środkami restrukturyzowała gospodarki krajów posocjalistycznych. Jak pisałam, priorytetem politycznym i ekonomicznym było odejście od gospodarki planowania centralnego i „stworzenie” gospodarki wolnorynkowej. Siłą rzeczy ta potężna restrukturyzacja wygenerować musiała tych, których Zygmunt Bauman nazywa ludźmi zbędnymi, ludźmi odpadami i ludźmi na przemiał (Bauman, 2005, 2006). W obrazie społecznym państw posocjalistycznych pojawili się więc nowi ubodzy, których praca była nisko wyceniana, albo którzy wprost stali się bezrobotni. Emigracja zarobkowa nie pojawiła się jednak w Polsce tuż po 1989 r., ale była w niej wcześniej. Trzy dekady zmian ekonomicznych i politycznych poważnie zmieniły nie tylko obraz polskiego emigranta, ale także zmieniły polityczne i ekonomiczne myślenie o emigrantach, którzy są dziś traktowani jak „skarb narodowy”. Okazują się oni nie tylko siłą polityczną przy okazji kolejnych wyborów parlamentarnych czy prezydenckich, ale stanowią przede wszystkim potężny kapitał ekonomiczny i społeczny.

Nowym zjawiskiem w Polsce jest staje rosnąca populacja imigrantów zarobkowych. Zmienia się jej struktura społeczna, a możliwość lepszego życia - jak dowodzi zrekonstruowana biografia rodziny imigranckiej - uwodzi niektórych na tyle, że decydują się oni osiedlić w Polsce ze swymi rodzinami na dłużej lub na stałe. Imigranci zarobkowi to poważny kapitał ekonomiczny i społeczny, ale kłopot w tym, że imigranci zarobkowi (szczególnie w pierwszym pokoleniu) jak przekonuje Zygmunt Bauman - poważnie zasilają populację ludzi-odpadów czy też ludzi na przemiał. Tworzą oni specyficzny margines rynku zatrudnienia, podejmując się pracy, której nikt inny wykonywać nie chce ze względu na to, że jest ona niskopłatna i pozbawiona prestiżu. Jak próbowałam pokazać w niniejszym artykule, imigranci zarobkowi w Polsce znacząco powiększają swoją populację od 
chwili wejścia w życie „programu 500+”, a więc od momentu, gdy rodzima polska ludność najniżej sytuowana mogła porzucić pracę, która była/jest tania, i której się nie szanuje, ale która wcześniej pozwalała „dorobić” do domowego budżetu. Cudzoziemcy zarabiają o ok. 25\% mniej niż wszyscy pracujący, co oznacza, że mogą być oni także dyskryminowani na rynku pracy. Przedstawiona biografia rodziny ukraińskiej - w kontekście zarysowanej społecznej sytuacji imigrantów zarobkowych - uświadamia dwa problemy: (1) uznania ekonomicznego imigrantów; (2) uznania kulturowego imigrantów.

Jako pracownicy legalnie zatrudnieni, imigranci są chronieni przez polskie prawo, ale pomimo tej ochrony są oni także bezbronni wobec praktyk, w których niewolniczo wykorzystuje się m.in. ukraińskich pracowników, o czym raz na jakiś czas donoszą media (por. Müller, Szymańska, Szachowskoj, 2020). Trzeba zatem postawić pytanie o to, jak polskie prawo (nie)chroni pracowników cudzoziemców? Pytanie pozostawiam bez odpowiedzi, chociaż - już na podstawie doniesień medialnych - można ostrożnie wnioskować, że trudno jest dziś mówić o dobrej polityce uznania ekonomicznego cudzoziemców, choćby dlatego, że niedostatecznie monitorujemy - jako państwo - ten sektor zatrudnienia.

Innym problemem jest zabezpieczenie prawa cudzoziemców do ochrony własnego języka i kultury w szkole. Raport Najwyższej Izby Kontroli pt. „Kształcenie dzieci...” (2000) wskazuje, że wiele polskich szkół funkcjonuje tak, jakby uczniowie imigranci w polskiej szkole nie istnieli. Dzieci z tej grupy - oprócz dodatkowych lekcji języka polskiego - nie otrzymują koniecznego dla nich wsparcia psychologiczno-pedagogicznego, a nauczyciele nawet nie potrafią dostrzec, że uczeń cudzoziemiec może być w poważnym stresie psychologicznym.

Analiza wywiadów i wniosków ze wspomnianego raportu pokontrolnego NIK (2020) nie jest optymistyczna w kwestii uznania kulturowego uczniów cudzoziemców w polskiej szkole. Oprócz przytoczonych, dodatkowych lekcji języka polskiego w szkole nie oferuje lekcji z zakresu własnego języka i kultury. Szkoła nie oferuje nawet zajęć z zakresu edukacji wielokulturowej i międzykulturowej, które mogłyby z powodzeniem dbać o dwukulturowe potrzeby uczniów cudzoziemców i równocześnie uwrażliwić polskich uczniów na różnicę kulturową. W niektórych przypadkach - jak dowodzi niniejszy artykuł - dochodzić może do sytuacji, gdy ojczysta kultura i język ucznia cudzoziemca, nie będąc przedmiotem troski szkoły, w jego świadomości traci prestiż. Zrekonstruowana biografia ukraińskiej rodziny to egzemplifikacja tych sytuacji edukacyjnych, w których uznanie społeczne (ale nie kulturowe!) to efekt angażowania się uczniów cudzoziemców w codzienność szkolną poprzez język polski. U podstaw tego procesu tkwi świadomość, że aby zostać w Polsce na stałe, trzeba bardzo dobrze nauczyć się języka polskiego. 
Polska polityka wielokulturowości skupia się przede wszystkim na mniejszościach rodzimych - na mniejszościach etnicznych i zadomowionych mniejszościach narodowych - i ma swoją reprezentację w Ustawie o mniejszościach narodowych z 2005 r. Ustawa ta jednak nie zabezpiecza praw kulturowych nowo przybyłych mniejszości, w tym obywateli Ukrainy, którzy przyjeżdżają do Polski w poszukiwaniu lepszej pracy bądź lepszego życia. Jak pokazałam w niniejszym artykule, Polska jest państwem, które odniosło wymierny sukces transformacyjny i może być/jest spostrzegana jako państwo, w którym żyje się lepiej. Nie tylko więc Polska potrzebuje pracowników cudzoziemców, aby rozwijała się jej gospodarka i aby system ubezpieczeń społecznych pozostał wydolny. Polska jest także państwem, którego potrzebują niektórzy cudzoziemcy, aby poprawić jakość swojego życia. Polska polityka wielokulturowości powinna zatem pochylić się nad problemami ekonomicznymi i kulturowymi imigrantów, choćby z tego powodu, że obie strony mają żywotny interes w zrównoważonej kooperacji.

\section{Bibliografia}

Arendt, H. (2000). Kondycja ludzka. Tłum. A. Łagodzka. Warszawa: Fundacja Aletheia. Arystoteles (1983). Metafizyka. Tłum. K. Leśniak. Warszawa: Państwowe Wydawnictwo Naukowe.

Barzykowski, H., Grzymała-Moszczyńska, H., Dzida, D. i in. (2013). One sq wśród nas. Wybrane zagadnienia diagnozy psychologicznej dzieci i młodzieży w kontekście wielokulturowości oraz wielojęzyczności. Warszawa: Ośrodek Rozwoju Edukacji.

Bauman, Z. (2005). Życie na przemiał. Tłum. T. Kunz. Kraków: Wydawnictwo Literackie. Bauman, Z. (2006). Praca, konsumpcjonizm i nowi uboczy. Tłum. S. Obirek. Kraków: Wydawnictwo WAM.

Bos-Karczewska, M. (2015). Let’s get connected! Sukces emigrantów sukcesem Polski. W: S. Szultka (red.), Jak włq̨czyć emigrację do rozwoju Polski? (s. 31-34). Gdańsk: Instytut Badań na Gospodarką Rynkową.

Boski, P. (2019). Kulturowe ramy zachowań społecznych. Podręcznik psychologii międzykulturowej. Warszawa: Wydawnictwo Naukowe PWN - Academica Wydawnictwo SWPS.

Domarecki, K. (2015). Świeże spojrzenie z oddali. W: S. Szultka (red.), Jak włq̨czyć emigrację do rozwoju Polski? (s. 15-16). Gdańsk: Instytut Badań na Gospodarką Rynkową.

Gadamer H.-G. (2004). Prawda i metoda. Tłum. B. Baran. Warszawa: Wydawnictwo Naukowe PWN.

Janowski, M. (1998). Polska myśl liberalna do 1918 roku. Kraków-Warszawa: Wydawnictwo Znak, Fundacja im. Stefana Batorego.

Kożyczkowska, A., Młynarczuk-Sokołowska, A. (2018). Kulturowe konteksty dzieciństwa. Szkice antropologiczno-pedagogiczne. Gdańsk: Wydawnictwo Naukowe Katedra. 
Kształcenie dzieci rodziców powracajq̨cych do kraju oraz dzieci cudzoziemców (2020). Informacja o wynikach kontroli. KNO.430.014.2019, nr ewid.42/2020/P?19/028/KNO. Warszawa: Najwyższa Izba Kontroli. Departament Nauki, Oświaty i Dziedzictwa Narodowego. Pobrane z: https://www.nik.gov.pl/kontrole/P/19/028/.

Lazarus, R.S. (1993). From psychological stress and emotions: A History of Changing Outlooks. Annual Review of Psychology, 44, s. 1-21.

Lazarus, R.S. (1998). The stress and coping paradigm. W: R.S. Lazarus, Fifty years of the research and theory of R.S. Lazarus: an analysis of historical and perennial issues (s. 182-219). Mahwah - New Jersey - London: Lawrence Erlbaum Associates Inc.

Ministerstwo Rozwoju, Pracy i Technologii (2020). Zezwolenia na pracę cudzoziemców. Dane zbiorcze 2008 r., 2009 r., 2010 r., 2011 r., 2012 r., 2013 r., 2014 r., 2015 r., 2016 r., 2017 r., 2018 r., 2019 r. Pobrane z: https://psz.praca.gov.pl/web/urzad-pracy/-/8180075-zezwolenia-na-prace-cudzoziemcow.

Mrugała, G., Nasiński P. (oprac.). (2020). Cudzoziemcy w polskim systemie ubezpieczeńspołecznych, Departament Statystyki i Prognoz Aktuarialnych. Warszawa: Zakład Ubezpieczeń Społecznych. Pobrane z: https://www.zus.pl/documents/10182/2322024/ Cudzoziemcy+w+polskim+systemie+ubezpieczeń+społecznych+2020.pdf/8a6937179b66-3e70-737b-28fe827ea41e.

Müller, P., Szymańska, A., Szachowskoj, E. (2020). Niewidzialni. Ukraińcy pracuja jakniewolnicy. Pobrane z: https://extra.wyborcza.pl/ukraincy-w-polsce.

Stiglitz, J.E. (2004). Globalizacja. Tłum. H. Simbierowicz. Warszawa: WydawnictwoNaukowe PWN.

Stosunek do innych narodów. Komunikat z badań nr 17/2019. (2019). Warszawa: Centrum Badania Opinii Społecznej. Pobrane z: https://cbos.pl/SPISKOM.POL/2019/K_017_19. PDF.

Stosunek do innych narodów. Komunikat z badań nr 31/2020. (2020). Warszawa: Centrum Badania Opinii Społecznej. Pobrane z: https://www.cbos.pl/SPISKOM.POL/2020/K_031_20.PDF.

Strama, A. (2017). Czy Polska to kraj, z którego tylko się wyjeżdża? W: H. Thiollet (red.), Migranci, migracje. O czym warto wiedzieć, by sobie wyrobić własnej zdanie. Tłum. M. Szczurek (s. 193-197). Kraków: Wydawnictwo Karakter.

Szafrańska, A. (2019). Nauczyciele z pogranicza polsko-czeskiego o swoich sąsiadach. Pedagogika Społeczna, 2, s. 149-162.

Szafrańska, A. (2017). Tak dalecy czy/i tak bliscy? Obraz Czechów w percepcji polskichnauczycieli. Rocznik Lubelski, 3, s. 110-136.

The World Bank (2020b). GDP per capita (current US\$) - Ukraine, Poland. Pobrane z:https://data.worldbank.org/indicator/NY.GDP.PCAP.CD?locations=UA-PL.

The World Bank (2020a). GDP (current US\$) - Ukraine, Poland. Pobrane z:https://data. worldbank.org/indicator/NY.GDP.MKTP.CD?locations=UA-PL.

The World Bank (2020c). GDP per capita, PPP (current international \$) - Ukraine, Poland.Pobrane z:https://data.worldbank.org/indicator/NY.GDP.PCAP.PP.CD?locations=UA-PL.

Ustawa z dnia 6 stycznia 2005 r. o mniejszościach narodowych i etnicznych oraz o języku regionalnym. Dz.U. 2005, nr 17, poz. 141. 